\title{
How to Make Employment Services Useful for Creating Youth Employment: Bridging the Gap between Policy and Practice
}

\author{
Ji-Hyun $\mathrm{Oh}^{1}$ and Young-Min Lee ${ }^{2 *}$ \\ ${ }^{1}$ Graduate Program of Human Resource Development Policy, \\ Sookmyung Women's University \\ Cheongpa-ro 47-gil 100 (Chungpa-dong 2ga), Yongsan-gu, Seoul, 04310, Korea \\ ${ }^{2}$ Graduate school of Human Resources Development for Women, \\ Sookmyung Women's University \\ Cheongpa-ro 47-gil 100 (Chungpa-dong 2ga), Yongsan-gu, Seoul, 04310, Korea \\ ${ }^{1}$ successjh05@naver.com, ${ }^{*}$ ymlee@sookmyung.ac.kr
}

\begin{abstract}
The purpose of this study is to take a look at various youth employment policies operated by each government agency based on the fundamental causes and issues of serious unemployment among youth, and to propose a plan to facilitate employment accordingly. Therefore, the employment facilitation plan to expand the employment for youth may largely be classified into six categories. First, through tailored education that reflects corporate demands, aggressive improvement in the government system is required. Second, there is a need for general overhaul to enhance the qualitative level of participating companies in the SME youth internship, publicity of the project system and field instruction and management strengthening for participating workers. Third, there is a need to structure the government-level system to provide information from career support for youth to gaining employment in a one-stop service. Fourth, there is a need to check the categories as a general core project to simplify the youth occupation project and the sense of effectiveness of youth employment policies for the youth generation. Fifth, there is an urgent demand for facilitation of a win-win employment situation and voluntary participation of business enterprises in the expansion of youth employment. Sixth, there is a need to close the gap and improve the work environment in small and medium enterprises. Notwithstanding the fact that unemployment in youth has emerged as a major social issue, there is a clear phenomenon suggesting that the youth generation still does not take advantage of employment opportunities in SMEs.
\end{abstract}

Keywords: Youth, Employment Expansion, Employment Service, Youth Employment Policy and Practice, Restructuring Plan for Employment Service

\section{Introduction}

The issue of youth unemployment has emerged as one of the biggest social issues in the Korean society as the initial employment time for the youth, the age ranges from 15 years to 24 years old as it is applicable to non-economically active population, has increased from 22.5 years of age in 2004 to 23.5 years of age in 2013, due to slowdown in economic growth, delay of reform in labor market, complicated issues and advancement of college education that is isolated from the field demand, as well as preparing for employment with beefing up the resume and so forth. Comparing the youth employment rate with advanced countries in terms of employment as of 2013, Korea was at $39.7 \%$ while Germany was at $57.7 \%$, Switzerland was at $69.7 \%$, and OECD countries were at $50.9 \%$, suggesting that there was a clear gap [1-2].

* Corresponding Author 
A recent government policy trend has focused on the youth employment policy to reduce unemployment among youth, and there are positive signals emerging such as an increase in employment rate and number of employed youth. As of April 2015, the number of employed youth in Korea (15 29 years of age) has increased from 85,000 persons to 3,902,000 persons compared to the same month in the previous year with a $1.0 \%$ increase in the employment rate to $41.1 \%$; however, the number of the unemployed increased by approximately 40,000; thus having 406,000 unemployed with an increase of $0.6 \%$ to record $9.3 \%[3-4]$. Therefore, the government held a joint meeting with private and public sector personnel including ministers of pertinent agencies and heads of six economic organizations on July 27, 2015. In this meeting, it announced a comprehensive measure to resolve the youth employment cliff situation including the main contents in moderation of short-term employment shocks for extension of the retirement year through job generation in the public sector and private sector, relieving the mismatch in fieldoriented HR advancement, expansion and efficiency of youth support infrastructure and so forth. In addition, in order to facilitate employment among youth, government agents and local governments are devising and introducing various youth employment policies and supporting the employment expansion service for youth.

Notwithstanding such a situation, following the expansion of university graduates who enter into the labor market with a temporary increase in the baby boomer generation, socalled "eco-generation" along with the increase in labor expense burden of business enterprises by implementing the obligation for extension of retirement age in 2016, the problems of youth employment will be aggravated even further in the next 3 4 years[5]. Accordingly, the slowdown in youth employment which is the foundation of the labor market as it is the backbone of the Korean economy has been the main factor behind worsening of the economic structure due to worsening labor productivity and growth potential, suggesting that there is a need for a review on various employment expansion services for youth. Therefore, the purpose of this study is to present the education expansion rate among youth after looking into the youth employment service for each promotion work implemented on the basis of the youth considering the employment status and problems of youth. In order to address these objectives, research questions are as follow. First, what is the current employment service operated by each government agency for youth and its corresponding issues? Second, what are the restructuring plans for employment services for achieving youth employment expansion?

\section{Research Method}

The purpose of this study is to take a look at various projects implemented by the government for expanding the employment opportunities for the youth generation on the basis of issues and causes of complex unemployment among youth through prior studies and to present a plan to structure the employment service for youth accordingly. In order to accomplish the goal of this study, the authors of this study has contemplated recent theses and publications, as well as various data presented by the government during the years 2010 2015. The study has been designed by using the famous academic publication database, Korean Education and Research Information Service (KERIS), Research Information Sharing Service (RISS), and Ministry of Employment and Labor, Ministry of Education, Ministry of Strategy and Finance that have undertaken numerous researches as well as the data from the online sites, such as Google and others. The key words for the study were youth generation, employment expansion, employment service, youth employment policy and practice, re-structuring plan for the employment service and so forth. Through the process mentioned above, a total of 15 theses and 20 government related sites were visited and the data excerpted from them were finally used. As Torraco (2005) mentioned that the purpose of synthesizing the literature is to review a body of research and to focus on key issues, the core findings from the literature review on 
Human Resource Development were synthesized and reported to accomplish the research purpose [6].

\section{Literature Review}

\subsection{Status of the Youth Employment Policy}

The government has been undertaking various projects for youth employment through the 'Special Act on the Promotion of Youth Employment'. This law was first devised as part of the 'comprehensive unemployment measure (1998)' established after the foreign currency crisis in 1997 [7], and thereafter, it has been enacted on March 5, 2004 for the purpose of reducing youth unemployment and achieving continuous economic development as well as social stability by expanding employment for the unemployed youth and domestic and overseas occupational competency development training to deal with a depressed economy, industrial hallowing from overseas transfer of domestic manufacturers and so forth [8].

During the Kim Dae-joong administration, the 'comprehensive unemployment measure' has sustained with the main contents of direct job providing policy for 5 years (1998 2002), occupational education and training, structuring of a comprehensive occupational information system and other infrastructure for supporting the occupational work performance. From 1999, the target has been the youth, women, the disabled, daily workers, the long-term unemployed, the aged, unemployed in financial and public sectors and so forth that begin the 'measure for each characteristic of the unemployed' [9].

In addition, the Roh Moo-hyun administration showed the need for preparing fundamental measures from a long-term point of view for slowdown in economic growth, vulnerable issues in infrastructure for youth employment, distance school education from the field and so forth, and not just a temporary issue of foreign exchange crisis, or the fundamental issue in youth unemployment. Accordingly, from 2003, measures to promote youth employment have been announced five times, and the "Special Act on Relieving Youth Unemployment ' was enacted in March 2004 which made it mandatory for the government investment institutions and the government-chartered agencies to hire $3 \%$ or more of their full capacity in order to employ the unemployed youth every year.

The Lee Myung-bak regime curtailed the policies with low efficiency, while the employment support policy for classes that have difficulty in obtaining employment, overseas employment of youths, employment-first and advance-second policy and others were actively promoted on the basis of outcome evaluation of the existing youth employment policy. Furthermore, the application period of the "Special Act on Relieving Youth Unemployment' was extended to December 31, 2013, and it was revised as the "Special Act on the Promotion of Youth Employment' in October 2009. This Act was again revised in May 2013 to extend up to December 31, 2018, and public institutions and it was obligatory for local public companies to newly hire to the full capacity for $3 \%$ for the 'effort' made to hire the youth employed (15 years of age $\sim 29$ years of age) for 3 years from $2014 \sim 2016$.

Thereafter, the Park Geun-hye government implemented the youth employment policy with the main contents of job generation and occupation creation for the youth, expansion of jobs for youth in public sector, hiring beyond the simple resume record, overseas employment and so forth [7]. Considering the problems of the youth employment situation, an additional supplementary budget was provided with an increase of 178.5 billion won in 11 youth job projects in 2015, including the internship system for SME, job-study simultaneous operation support, youth employment academy operation support, overseas employment support, youth employment career support, employment success package, generation of win-win employment support and others [10]. 
Looking into the main contents, on the basis of the year 2015, the government had a plan to support 300,000 persons in the 'employment success package project', but it plans to support a total of 60,000 additional persons, including 30,000 youths in the supplementary plan. The 'generation of the win-win employment support project' considers the obligation of full retirement at the age of 60 years in 2016, and it plans to provide support for 2 years with 10.8 million won for each newly hired youth (5.4 million won for a major company). In addition, through the 'youth employment academy support project', 1,000 persons majoring in the humanities who are seriously affected by the employment problems are additionally supported, and through the 'university creative job center' project, the employment support project in universities and budget are linked and integrated to revise the delivery system for the youth support business service [11].

\subsection{Status of Support for Youth Employment Service Operated by each Government Agency}

In order to reduce the employment problems of youth, following actions have been taken in the form of a representative youth employment policy for each youth employment rate, based on the Special Act on Promotion of Youth Employment, the details of which are shown in Table 1.

Table 1. Status of Support for Youth Employment Service Operated by Each Government Agency

\begin{tabular}{|c|c|c|}
\hline Classification & Business Name & Main Contents \\
\hline \multirow{2}{*}{$\begin{array}{l}\text { The Ministry of } \\
\text { Employment } \\
\text { and Labor } \\
\text { Affairs [ 12 ] }\end{array}$} & $\begin{array}{l}\text { Daily Learning } \\
\text { Supplementary } \\
\text { System }\end{array}$ & $\begin{array}{l}\text { - In September } 2013 \text {, work based learning, which } \\
\text { is globally spreading to Germany, Switzerland, } \\
\text { Australia and the United Kingdom for } \\
\text { apprenticeship, was introduced to meet to the } \\
\text { reality in Korea with the purpose of the project } \\
\text { being to advance the working-level personnel } \\
\text { development to meet the corporate demand. } \\
\text { - This system went through the pilot project as of } \\
\text { the end of the year } 2013 \text {, and } 1,721 \text { companies had } \\
\text { participated as of September } 17 \text {, 2014, but the } \\
\text { participation of major enterprises was very slow } \\
\text { and the participation of SMEs with less than } 300 \\
\text { employees accounted for } 95 \% \text {. } \\
\text { - There were average } 6 \text { trainees per enterprise, } \\
\text { average training period was } 17 \text { months, and average } \\
\text { wage was } 1.63 \text { million won, and the operation was } \\
\text { created by government-leading works due to the lack } \\
\text { of voluntary participation of companies. }\end{array}$ \\
\hline & $\begin{array}{c}\text { Youth } \\
\text { Employment } \\
\text { Internship } \\
\text { System for } \\
\text { SME }\end{array}$ & $\begin{array}{l}\text { - It is purported to provide internship opportunity } \\
\text { to youth not employed in SME and enhance job } \\
\text { competency and gain the possibility of } \\
\text { employment for regular positions. } \\
\text { - The qualification for participation of youth is } 15 \\
\text { years or older to } 34 \text { years or younger with less than } 6 \\
\text { months of employment experience, and } \\
\text { implementation of the business with } 5 \text { or less full-time } \\
\text { workers for the "company subject of priority support }\end{array}$ \\
\hline
\end{tabular}




\begin{tabular}{|c|c|}
\hline & $\begin{array}{l}\text { under the Employment Insurance Act (including SME } \\
\text { under the Framework Act of Small and Medium } \\
\text { Enterprises). } \\
\text { - Contents of support include } 600,000 \text { won per } \\
\text { month during } 3 \text { months of the internship period with } \\
\text { conversion into a regular position, } 3.9 \text { million won as } \\
\text { support for hiring } 6 \text { months or longer ( } 650,000 \text { won } \\
\text { per month), and } 3 \text { million won for manufacturing } \\
\text { business and } 1.8 \text { million won for other business types } \\
\text { when working for a certain period if the youth intern is } \\
\text { converted into a regular position. }\end{array}$ \\
\hline $\begin{array}{c}\text { Youth } \\
\text { Employment } \\
\text { Center in } \\
\text { Universities }\end{array}$ & $\begin{array}{l}\text { Youth Employment Center should be } \\
\text { established in universities and specialization of } \\
\text { private employment service institution with high } \\
\text { level of recognition should be facilitated to provide } \\
\text { various employment support services to university } \\
\text { students. } \\
\text { - Universities should provide the space and facilities } \\
\text { for operating the university youth employment center } \\
\text { and the operating institution should hire and arrange } \\
\text { private consultants to operate the center. } \\
\text { - With respect to support, the universities will } \\
\text { receive support for regular universities and colleges, } \\
\text { industrial colleges and junior colleges under Article } 2 \\
\text { of the Higher Education Act, and the operating } \\
\text { institutions shall receive support for free job } \\
\text { placement services and fee-charging job placement } \\
\text { services under Article } 18 \text { and Article } 19 \text { of the } \\
\text { Employment Service Act. } \\
\text { - Contents of the support include consultant labor } \\
\text { expense (university to match for } 40 \% \text { or more) ( } 2.5 \\
\text { million won per month for each person), operation } \\
\text { expense ( } 8 \text { 10 million won per year), and employment } \\
\text { program costs (5 6 million won per year). }\end{array}$ \\
\hline $\begin{array}{c}\text { Creative Job } \\
\text { Center in } \\
\text { Universities }\end{array}$ & $\begin{array}{l}\text { Expansion and operation of the center in } \\
\text { universities by strengthening the link for youth } \\
\text { employment support functions in the university as } \\
\text { they are scattered around for each department. } \\
\text { - In future, it is scheduled to strengthen the } \\
\text { employment opportunities and provide business start- } \\
\text { up package for youth and university students through } \\
\text { close collaboration with the employment zone } \\
\text { (matching and linkage on the basis of the personnel } \\
\text { demand of enterprises and job-seeking information for } \\
\text { youth by promoting the youth job supporting projects } \\
\text { and others for the project of employment stepping } \\
\text { stone and social tailored study project and so forth } \\
\text { within the Occupation Innovation Center (Ministry of } \\
\text { Science, ICT and Future Planning). }\end{array}$ \\
\hline
\end{tabular}




\begin{tabular}{|c|c|c|}
\hline & $\begin{array}{l}\text { Employment } \\
\text { Bridge-stone } \\
\text { Program }\end{array}$ & $\begin{array}{l}\text { Under the leadership of major companies } \\
\text { (public institutions) and creative economy } \\
\text { innovation center, high quality occupational } \\
\text { training should be implemented and active support } \\
\text { should be provided for hiring and business start up } \\
\text { for an outstanding company for those who } \\
\text { complete the program. } \\
\text { - Determination of the status of a company that } \\
\text { may participate, help in program design, publicity } \\
\text { and expansion from the second half of the year } \\
2015 \\
\text { - Scheduled to implement training in large } \\
\text { companies and public institutions from the year } 2016 \text {. }\end{array}$ \\
\hline & $\begin{array}{c}\text { K-Move } \\
\text { School } \\
\text { (Support of } \\
\text { Overseas } \\
\text { Employment) }\end{array}$ & $\begin{array}{l}\text { - By identifying high quality overseas jobs, it } \\
\text { provides a tailored education program appropriate } \\
\text { to the demand of employment opportunity and then } \\
\text { links it to the overseas employment. } \\
\text { - Subjects receiving the support should be the } \\
\text { persons who do not have any cause of disqualification } \\
\text { for overseas employment as unemployed persons aged } \\
34 \text { years or younger ( } 3,000 \text { persons in the year 2015) } \\
\text { - Contents of support would be up to } 8 \text { million } \\
\text { won per person including education expenses, } \\
\text { airfares and so on. }\end{array}$ \\
\hline $\begin{array}{l}\text { The Korea } \\
\text { Federation of } \\
\text { SMEs }\end{array}$ & $\begin{array}{l}\text { SME youth } \\
\text { employment } \\
\text { Internship } \\
\text { system }\end{array}$ & $\begin{array}{l}\text { - This project was introduced in } 2009 \text { with an aim } \\
\text { to provide opportunity to enhance the occupational } \\
\text { capability of unemployed youth and youth } \\
\text { employment in regular positions to reduce the HR } \\
\text { shortages in SMEs. } \\
\text { - The qualification to participate in the subject of } \\
\text { support would be persons aged } 15 \text { years or older and } \\
34 \text { years or younger with less than } 6 \text { months of } \\
\text { employment and the enterprises that provide such a } \\
\text { support would be the SMEs with } 5 \text { or more full-time } \\
\text { employees. } \\
\text { - In order to enhance corporate participation, part of } \\
\text { labor expenses is paid by the Korea Federation of } \\
\text { SMEs to business enterprises for up to one year, and } \\
\text { the youth intern is paid wages by business enterprises } \\
\text { during the internship period, and this enables } \\
\text { provision of the employment support fund from } 1.8 \\
\text { million won to } 3 \text { million won for each business type } \\
\text { upon converting into a regular position [ } 5,2 \text { ]. }\end{array}$ \\
\hline $\begin{array}{l}\text { The Ministry of } \\
\text { Gender, } \\
\text { Equality and } \\
\text { Family [ } 13 \text { ] }\end{array}$ & $\begin{array}{c}\text { Career } \\
\text { Development } \\
\text { Center for } \\
\text { University } \\
\text { Women }\end{array}$ & $\begin{array}{l}\text { - This project is purported to enhance flawless } \\
\text { performance and HR facilitation to the } \\
\text { occupational work through career development and } \\
\text { employment support for highly educated women }\end{array}$ \\
\hline
\end{tabular}




\begin{tabular}{|c|c|c|}
\hline & & $\begin{array}{l}\text { under the premises that the occupational design of } \\
\text { women college students should be prepared in } \\
\text { colleges now. } \\
\text { - It provides a one-stop service for systematic career } \\
\text { development from career development to employment } \\
\text { support for women college students. } \\
\text { - After the pilot operation in } 5 \text { universities from } 2003 \\
\text { to } 2005 \text {, the program is expanded to support } 12 \\
\text { universities from } 2006 \text { and } 40 \text { universities from } 2015 \\
\text { (center support for } 17 \text { and program support for } 23 \text { ). }\end{array}$ \\
\hline & $\begin{array}{c}\text { Operation of } \\
\text { Cyber } \\
\text { Mentoring }\end{array}$ & $\begin{array}{l}\text { - Through indirect experiences in special knowledge, } \\
\text { advise and others of senior women (mentors), and it } \\
\text { supports the role model and network of women to } \\
\text { structure the future image of occupation. } \\
\text { - The subject of support is the subject for university } \\
\text { women, employment preparing women, beginning } \\
\text { women in the society, women who have discontinued } \\
\text { career and others. } \\
\text { - Contents of support are operated for online and } \\
\text { off-line mentoring, commissioning of successful } \\
\text { women for each field as the representative mentor } \\
\text { with open mentoring, online } 1: 1 \text { matching as well } \\
\text { as off-line group mentoring, special lecture and so } \\
\text { forth with various types of young women. }\end{array}$ \\
\hline \multirow{2}{*}{$\begin{array}{l}\text { The Presidential } \\
\text { Commission on } \\
\text { Youth [ 14 ] }\end{array}$} & $\begin{array}{c}\text { The } \\
\text { Presidential } \\
\text { Commission on } \\
\text { Youth }\end{array}$ & $\begin{array}{l}\text { - This project has the goal to advance human } \\
\text { talents in future as the foundation to structure the } \\
\text { trusting society as well as facilitating } \\
\text { communication with the youth, and it was } \\
\text { established under the Presidential Commission in } \\
\text { July } 2013 \text {. } \\
\text { - The intensive promotion work in } 2015 \text { would be } \\
\text { four-fold with detailed contents as follows: 1) job and } \\
\text { business start-up environment improvement, 2) } \\
\text { support for human advancement and career guidance, } \\
\text { 3) improvement of living conditions and protection of } \\
\text { rights of youth, and 4) expansion of youth } \\
\text { participation and communication. }\end{array}$ \\
\hline & $\begin{array}{l}\text { Door-to -door } \\
\text { Youth Bus }\end{array}$ & $\begin{array}{l}\text { Direct communication with many youths is } \\
\text { strengthened by listening to opinions of many youths } \\
\text { by visiting all youths around the country. } \\
\text { - Infrastructure to support the government and } \\
\text { private sector and to help solve various problems } \\
\text { related to the career and job of youth. } \\
\text { - Any youth } 19 \sim 39 \text { years old may participate in the } \\
\text { field without a separate application procedure, and it is } \\
\text { operated around the non-capital region where } \\
\text { information and infrastructure are relatively poor. }\end{array}$ \\
\hline
\end{tabular}




\begin{tabular}{|c|c|c|}
\hline \multirow{3}{*}{$\begin{array}{c}\text { Ministry of } \\
\text { Strategy and } \\
\text { Finance [ 15 ] }\end{array}$} & $\begin{array}{l}\text { Public Agency } \\
\text { Hiring-type } \\
\text { Internship }\end{array}$ & $\begin{array}{l}\text { - It is aimed at providing opportunity to strengthen } \\
\text { the employment competency of youth for the public } \\
\text { institution. } \\
\text { - Subjects for support should be hired from youths } \\
\text { under the 'Special Act on the Promotion of Youth } \\
\text { Employment ( } 15 \text { years old - } 34 \text { years old) in principle } \\
\text { but it is operated flexibly in consideration of work } \\
\text { relativity for each institution. } \\
\text { - Contents of support would be hiring at regular } \\
\text { positions for at least } 70 \% \text { of interns by the method of } \\
\text { hiring through the internship process for new } \\
\text { personnel. }\end{array}$ \\
\hline & $\begin{array}{c}\text { System of } \\
\text { Public Agencies } \\
\text { to Hire High- } \\
\text { School } \\
\text { Graduates }\end{array}$ & $\begin{array}{l}\text { - Refrain from over education or record-oriented } \\
\text { hiring and provide employment opportunity for high } \\
\text { school graduates at public institutions as part of social } \\
\text { equality. } \\
\text { - Subjects for support are persons who have recently } \\
\text { graduated from high school (age around } 18 \text { years) or } \\
\text { who claim to have equivalent knowledge, education } \\
\text { and technology } \\
\text { - Contents of support are discovered for duties } \\
\text { appropriate to the common characteristics of } \\
\text { institution such as general affairs, administrative } \\
\text { affairs, personnel, planning and support, accounting, } \\
\text { publicity, call center management, computerization, } \\
\text { accounting deposit and withdrawal and other common } \\
\text { works with hiring of high school graduates on the } \\
\text { basis of the works appropriate for public institutions. }\end{array}$ \\
\hline & $\begin{array}{c}\text { Dispatching } \\
\text { EDCF Overseas } \\
\text { Interns } \\
\text { (Expanding the } \\
\text { Overseas } \\
\text { Advancement of } \\
\text { Youth Interns) }\end{array}$ & $\begin{array}{l}\text { The purpose is to contribute to development } \\
\text { cooperation in professionals and support of flawless } \\
\text { overseas advancement for youths in Korea. } \\
\text { - Subjects for participation have no limits in age, } \\
\text { military service and academic record, and person not } \\
\text { eligible for qualification cause under the regulations } \\
\text { related to personnel at Export and Import Bank and } \\
\text { has no cause of disqualification for staying overseas. }\end{array}$ \\
\hline $\begin{array}{l}\text { Ministry of } \\
\text { Foreign Affairs }\end{array}$ & $\begin{array}{l}\text { ODA Youth } \\
\text { Internship }\end{array}$ & $\begin{array}{l}\text { The purpose is to enhance global competitiveness } \\
\text { and ODA specialization through hiring of youth } \\
\text { interns in field practical experiences in the KOICA } \\
\text { overseas office and ODA project institution, as well as } \\
\text { the development cooperation project. } \\
\text { - Subjects for support will be provided the priority } \\
\text { given to the unemployed persons aged } 18 \text { years or } \\
\text { older, persons fluent in local language with TOEIC } \\
\text { score of } 730 \text { or more, the disabled, the low income } \\
\text { class, children of multi-cultural families, and } \\
\text { competent persons from rural areas }\end{array}$ \\
\hline
\end{tabular}




\begin{tabular}{|c|c|c|}
\hline & & $\begin{array}{l}\text { - Subjects for support will be the term of } 6 \text { months to } \\
1 \text { year for ODA youth internship. }\end{array}$ \\
\hline \multirow{3}{*}{$\begin{array}{l}\text { Ministry of } \\
\text { Education }\end{array}$} & $\begin{array}{l}\text { Operation of } \\
\text { Global Field } \\
\text { Learning } \\
\text { Program }\end{array}$ & $\begin{array}{l}\text { Providing the opportunity for various global field } \\
\text { learning opportunities, including practical experience } \\
\text { in the overseas industrial field for university students } \\
\text { helps the career and experience design and } \\
\text { advancement in the core human talent equipped with } \\
\text { global senses. } \\
\text { - Subjects for support will be domestic university } \\
\text { (junior colleges) students and recently graduated } \\
\text { students (preferential treatment of the classes } \\
\text { vulnerable for employment). } \\
\text { - The requirement for support should be the ones } \\
\text { who satisfy certain academic regulations, have fluency } \\
\text { in foreign language as well as are selected by the } \\
\text { screening procedure for each business in order to } \\
\text { dispatch them overseas. }\end{array}$ \\
\hline & $\begin{array}{c}\text { Expansion of } \\
\text { General High } \\
\text { School } \\
\text { Occupation } \\
\text { Education }\end{array}$ & $\begin{array}{l}\text { It purports the facilitation of employment for } \\
\text { general high school graduates who wish to have an } \\
\text { occupation by providing occupational training } \\
\text { opportunities. } \\
\text { - Subject for support will be the third year high } \\
\text { school students who hope to gain employment after } \\
\text { graduating from high school } \\
\text { - Subjects for support will be the third year general } \\
\text { high school students who intend to find employment } \\
\text { by using the public and private occupational training } \\
\text { institutions to support the educational expenses in } \\
\text { operating the occupational education programs for one } \\
\text { year (manufacturing, service fields and others) or a } \\
\text { short-term ( } 1 \text { semester). }\end{array}$ \\
\hline & $\begin{array}{c}\text { Personnel to } \\
\text { Support Special } \\
\text { High } \\
\text { School/Meister } \\
\text { High School } \\
\text { Employment } \\
\text { Opportunities }\end{array}$ & $\begin{array}{l}\text { It aims to enhance employment competency of } \\
\text { special high schools/Meister high schools and link the } \\
\text { field professional acquisition and employment as } \\
\text { required from the students by the industry. } \\
\text { - Subjects for support will be the employment } \\
\text { support centers under the city or provincial board of } \\
\text { education, specialized high school, Meister high } \\
\text { school, general high school, industrial information } \\
\text { school and joint practical centers } \\
\text { - Contents of support would help in the arrangement } \\
\text { of professional personnel equipped with industrial } \\
\text { experience to support employment. }\end{array}$ \\
\hline $\begin{array}{l}\text { Youth Hope } \\
\text { Fund }\end{array}$ & $\begin{array}{l}\text { Youth Hope } \\
\text { Foundation }\end{array}$ & $\begin{array}{l}\text { - With the major compromise of labor, management } \\
\text { and politics, the president directly proposed to help in } \\
\text { resolving the youth problems, including job situation, } \\
\text { in the Cabinet Meeting (September 15, 2015). }\end{array}$ \\
\hline
\end{tabular}




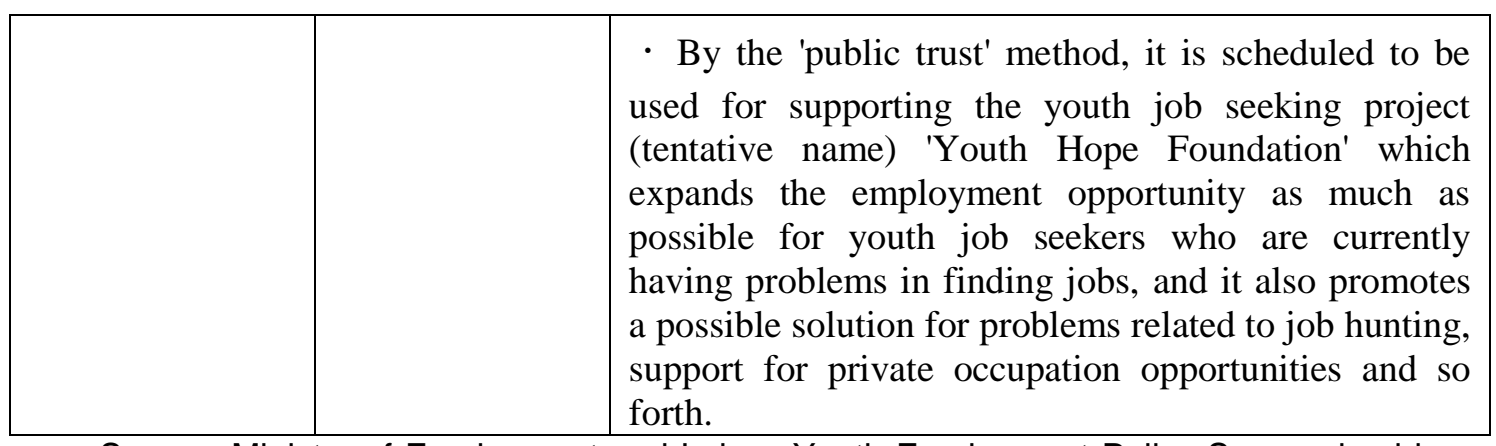

Source: Ministry of Employment and Labor, Youth Employment Policy Summarized in One Volume, Sejongsi (2015) [16]

\section{Issue of Youth Employment Service for Expanding Youth Employment and Scheme for Restructuring}

\subsection{Task 1: Need for Active System Improvement by the Government to Nurture Competent Human Resources}

The following is the suggestion of the plans for restructuring on the basis of issues in the youth employment service that cause employment difficulty among the youth, issues and expansion of youth employment. First, there is a need for active system improvement by the government in order to develop appropriate personnel as required on the site through tailored education that reflects the corporate demand. Korea has a substantially higher college advancement rate of youths even among the OECD countries; however, the youth unemployment rate is socially troublesome to the extent that there is a new term 'youth employment cliff'. It indicates that there is a growing problem of employment difficulty for youth due to the gap in education and qualification level that is required by business enterprises from youth and the lack of jobs preferred by the youths and mismatch phenomenon related to jobs of unable to find the right persons to assign them to a proper place and at a proper time which could cause or aggravate employment difficulties of youths. Therefore, since 2013, the government has developed the national competency standard (NCS) that is systematized for each industrial field and for each level by the state with the contents of knowledge, technology, manner and so forth that are required to perform the duties in the industrial field, and it began to implement full-scale around junior colleges from 2015, but the result is yet to be determined. Therefore, with respect to the education and training phase, opinions of business enterprises actually reflect that revision of the working level education system is required to perform the duties in corporate affairs and industrial fields [17].

\subsection{Task 2: Need for an Overall Review of Business in the Youth Intern System for SMEs}

Second, there is a need for a general review of business with enhancement of the qualitative level for business enterprises, publicity of business system, field instruction for participating workers and business that includes management strengthening by the enterprises that participated in the 'youth intern system for SMEs'. In fact, this system had a positive effect of making a contribution to employment of unemployed youths for regular positions in SMEs, but notwithstanding this fact, there are cases reported for simply repetitive works, such as, chores, cleaning, document copying and so forth that are not helpful for accumulating personal capital and employment preparation by the participating enterprises with the participating workers as subjects, thus showing the problems in qualitative management. Accordingly, there is a need for practical field 
instruction and management strengthening to be helpful for employment of participating workers and it is necessary to simplify the application procedure.

\subsection{Task 3: Need for Structuring the Government-level System to Provide a One- stop Service}

Third, there is a need to structure the government-level system to provide a one-stop service for the information required from career support to employment of youth. Currently, the central government and local governments undertake various youth employment policies and there is a growing voice of dissent about repeated budget investment from overlapping policies [18]. In addition, when engaging in job search activities, youth complain about the difficulty in obtaining employment information $(22.5 \%)$ and they have significant difficulty due to the lack of information on outstanding companies even if they intend to gain employment in SMEs by lowering their expectation. Thus, there is a dire need for youth-friendly information along with the information service with the field senses for information provision and understanding of strong and small enterprises.

\subsection{Task 4: Need for Checking the Categories as a General Core Project for Youth Employment Projects}

Fourth, there is a need to check the categories as a general core project to simplify the youth occupation project and the sense of effectiveness of youth employment policies for the youth generation. Currently, various government agencies have undertaken projects to facilitate youth employment, and this requires enhancement of sensitivity for generalizing and simplifying the youth employment projects in a few core projects as the temporary support policy to repeat and regenerate existing measures.

\subsection{Task 5: Need for Facilitation of a Win-win Employment Situation and Voluntary Participation of Business Enterprises}

Fifth, there is an urgent need for facilitation of a win-win employment situation and voluntary participation of business enterprises for expansion of youth employment. The government agencies implement various youth employment policies, including internship for youths, but due to the lackadaisical participation of business enterprises, including major companies, there are many problems in the qualitative aspect. Therefore, there is a need for voluntary participation of companies through the labor market, and it is necessary to form consensus of labor, management and academic sectors as well as a joint effort for implementation to build up the eco-system of a win-win employment situation for youth employment. In addition, it is necessary to perform a review of the plan to enhance the effectiveness of the project together with preparation of a concrete plan for creating youth employment.

\subsection{Task 6: Need for Closing the Gap and Improving the Work Environment in SMEs}

Sixth, there is a need to close the gap and improve the work environment in small and medium enterprises. Notwithstanding the fact that unemployment in youth has emerged as a major social issue, there is a clear phenomenon suggesting that the youth generation still does not take advantage of employment opportunities in SMEs. This is attributable to poor work environment compared to that in major companies, low labor costs, long working hours Ed: Please review the change and so forth. Hence to promote youth employment, it is necessary to consider improvement in working conditions, support for labor expenses, revision of the work shift system to replace long working hours, reduction 
in employment of foreigners by SME and so forth, in order to successfully apply the outstanding youth employment policy to SME.

\section{Conclusions}

There is a view that the cause of high youth unemployment is high expectation of youths due to high rate of advancement into higher education institutions, difficulty in finding HRs for SMEs and so forth, but it is imperative to take a look at the contradiction in the social structure in Korea rather than holding the youths accountable for the present youth employment cliff status in terms of lack of high-profile jobs to satisfy the youth, poor labor environment, change in the employment structure, preference of companies for experienced personnel, inefficient support system for youth employment service and so forth. Under the global economic crisis, the time has come to convert the economic and social paradigm into a win-win situation of capital and labor with the expansion of understanding that continuous economic growth and welfare expansion come through labor effort.

\section{References}

[1] Joint of Relevant Ministries, School to Occupation: Youth Employment Policy for Each Job Phase, (2014) April 15.

[2] World Association of Public Employment Services. Retrieved from http: www. http://wapes.org.

[3] Y. B. Kim, "The Actual Status of Youth Labor Market and Youth Employment Policy", Monthly Labor Review, edition, (2015) July 2015, pp. 5-14.

[4] National Statistical Service, Economically Active Population Survey, (2015).

[5] Press Release of the Ministry of Strategy and Finance, Tomorrow for Youth, Hope for Future Generation, Comprehensive Measure for Relieving Youth Employment Cliff, (2015) July 27.

[6] R. J. Torraco, "Writing integrative literature reviews: guidelines and examples", Human Resources Development Review, vol. 4, no. 3. (2005), pp. 356-367.

[7] S. M. Shin, M. S. Min and S. Y. Kwon, "The State of Unemployed Young Women and Employment Policy Issues", The Journal of Employment and Career, vol. 3, no. 2, (2013), pp. 41-63.

[8] "Korea Law Information Center", Retrieved from http: www.law.go.kr.main.html.

[9] Ministry of Labor, Unemployment Measures White Paper on Five years of People's Government(from 1998 to 2002), Gyeonggido (2002).

[10] S. H. Kim, "Labor Market Restructuring of Park's Government and the Revision of Employment Policies for Young", Labor Research, vol. 31, (2015), pp.5-37.

[11] Ministry of Employment and Labor, Presentation Data from the Office of Young Women's Employment Policy, September, vol. 23, (2015).

[12] Ministry of Employment and Labor, Retrieved from http://www.mogl.go.kr.

[13] Ministry of Gender, Equality and Family, Retrieved from http://www.mogef.go.kr.

[14] Presidential Commission on Youth, Retrieved from https://www.young.go.kr.

[15] Ministry of Strategy and Finance, Retrieved from http://www.mosf.go.kr/main/main.jsp.

[16] Ministry of Employment and Labor, Youth Employment Policy Summarized in One Volume, Sejongsi, (2015).

[17] J. H. Oh and Y. M. Lee, "Restructuring Employment Service for Expanding Youth Employment", Proceeding of Advanced Science and Technology Letters, Business, vol. 114, (2015), pp. 61-65.

[18] Y. M. Lee and J. H. Oh, "Policy Implications for Reforming Public Employment Center: How Can Service Performance Be Improved?", International Journal of u-and e-Service, Science and Technology, vol. 8, no. 9, (2015), pp. 173-184. 


\section{Authors}

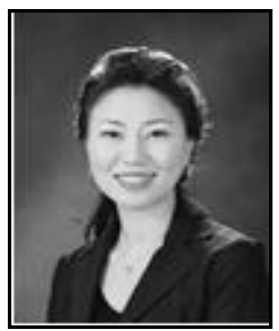

Ji-Hyun Oh, ABD, is adjunct professor of department of secretarial office administration at Baewha Women's University and training director of Korean Association of Administrative Professionals. Her main research areas include employment service, youth employment policy and human resources management. She has published papers in Korean and international scholarly journals, and conference proceedings. She has co-authored one book in her area of expertise.

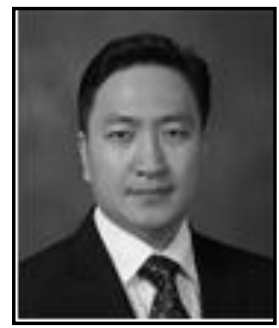

Young-Min Lee, Ph.D., is associate professor of graduate school of human resources development for women and the director of industry and academic cooperation center at Sookmyung Women's University. His main research areas include human resource development, workforce development and management of aging workforce. He has published five books and more than 100 papers in international periodicals and conference proceedings. 
International Journal of $u-$ and e- Service, Science and Technology Vol.9, No. 3 (2016) 